\title{
PERANAN KPU DALAM PEMBENTUKAN BUDAYA POLITIK DAN PERILAKU MEMILIH PADA PEMILUKADA KABUPATEN PATI 2017
}

\author{
Galuh Septianingrum, Nasiwan \\ Universitas Negeri Yogyakarta \\ galuh.septianingrum2015@student.uny.ac.id \\ iwan1uny@yahoo.co.id \& nasiwan@uny.ac.id
}

\begin{abstract}
Abstrak
Tujuan penelitian ini adalah mendeskripsikan peranan KPU Kabupaten Pati dalam melaksanakan pendidikan politik bagi masyarakat untuk membentuk budaya politik, membentuk perilaku memilih, dan mengatasi money politics pada Pemilukada serentak di Kabupaten Pati tahun 2017. Jenis penelitian ini adalah penelitian deskriptif dengan pendekatan kualitatif. Penentuan subjek penelitian dengan teknik purposive sampling. Penelitian ini menghasilkan, pertama, peranan KPU Kabupaten Pati dalam melaksanakan pendidikan politik bagi masyarakat untuk membentuk budaya politik terfokus pada pembentukan orientasi kognitif budaya politik, sedangkan pembentukan orientasi afektif dan evaluatif belum maksimal. Kedua, peranan KPU Kabupaten Pati dalam melaksanakan pendidikan politik bagi masyarakat untuk membentuk perilaku memilih berpusat pada pembentukan perilaku memilih rasional yaitu masyarakat diberi materi pengetahuan politik, didorong serta dimotivasi supaya memilih karena mempertimbangkan visi dan misi para calon, prestasi calon, track record (rekam jejak) serta kepribadian para calon sedangkan pembentukan perilaku memilih psikologis dan sosiologis dikesampingkan. Ketiga, peranan KPU Kabupaten Pati dalam melaksanakan pendidikan politik untuk mengatasi money politics, dengan cara mengajak masyarakat supaya tidak memilih karena uang (money politics) sebab berdampak negatif bagi keberlangsungan sistem politik di suatu negara. Pendidikan politik pada tahap input politik masih belum maksimal karena KPU Kabupaten Pati belum maksimal dalam memberikan materi pengetahuan politik tentang bagaimana mekanisme untuk melaporkan apabila terjadi kecurangan dalam proses Pemilukada Kabupaten Pati tahun 2017.
\end{abstract}

Kata Kunci: Pendidikan politik, budaya politik, perilaku memilih, money politics.

\section{Abstract}

The purpose of this study was to describe the role of the KPU Pati Regency in implementing political education for the community to form a political culture, to form voting behavior, and to overcome money politics in the Simultaneous General Election of Regional Head Pati Regency in 2017.This was a descriptive study using a qualitative approach. Determining the subject of research was conducted with a purposive sampling technique consisting. There were three findings in this study. First, the role of the KPU Pati Regency in implementing political education for the society to form a political culture only centered on the formation of cognitive orientation of political culture, while the formation of affective orientation and evaluatif orientation of political culture was still limited. Second, the role of the KPU Pati Regency in carrying out political education for the society to form a voting behavior was centered on the formation of rational voting behavior namely people were given the materials of political knowledge, encouraged and motivated in order to choose because of considering the vision and mission of the candidates, achievements of candidates, track record as well as the personality of the candidate, while the formation of psychological and sociological voting behavior was excluded. Third, the role of KPU Pati Regency in implementing political education to overcome money politics was by inviting people not to vote because of money which had a negative impact on the sustainability of the political system in a country. Political education at the input stage of politics was still devicient because KPU Pati Regency rarely gave materials of political knowledge of the mechanisms for reporting in case of fraud in the 2017 General Election in Pati regency.

Keywords: Political education, political culture, voting behavior, money politics. 


\section{Pendahuluan}

Di era desentralisasi seperti sekarang ini, yang diawali dengan lahirnya UndangUndang Republik Indonesia Nomor 32 Tahun 2004 tentang Pemerintahan Daerah di mana adanya otonomi daerah yang memberikan kesempatan kepada setiap daerah Provinsi, Kota, dan Kabupaten untuk melaksanakan pemilihan umum kepala daerah secara langsung. Hal ini tentu saja berbeda ketika era orde baru yang berkuasa selama 32 tahun (1966-1998), karena pada waktu itu Negara Indonesia masih menganut sistem sentralisasi sehingga kepala daerah dan wakil-wakil rakyat yang ada di daerah dipilih oleh DPRD. Pemilihan kepala daerah oleh DPRD ternyata membawa kekecewaan masyarakat. Hal tersebut dikarenakan:

Pertama, politik oligarki yang dilakukan DPRD dalam memilih kepala daerah, di mana kepentingan partai, bahkan kepentingan segelintir elit partai, kerap memanipulasi kepentingan masyarakat luas. Kedua, mekanisme pemilihan kepala daerah cenderung menciptakan ketergantungan kepala daerah terhadap DPRD. Dampaknya, kepalakepala daerah lebih bertanggungjawab kepada DPRD daripada kepada masyarakat. Dampak lebih lanjutnya adalah adanya kolusi dan money politics, khususnya pada proses pemilihan kepala daerah, antara calon dengan anggota DPRD. Ketiga, terjadi 'pencopotan' dan/atau tindakan over lain dari para anggota DPRD terhadap kepala daerah, seperti kasus di Surabaya dan Kalimantan Selatan, yang berdampak pada gejolak dan instabilitas politik dan pemerintahan lokal (Romli, 2008, p.1).

Diadakannya pemilihan umum kepala daerah secara langsung, diharapkan dapat mengatasi permasalahan akibat pemilihan kepala daerah oleh DPRD, sehingga rakyat yang ada di daerah Provinsi, Kota, dan Kabupaten diberi kesempatan untuk memilih kepala daerah atau wakil rakyat yang ada di daerahnya secara langsung. Seperti halnya di Kabupaten Pati yang telah melaksanakan otonomi daerah dengan mengadakan pemilihan umum kepala daerah secara langsung untuk memilih bupati dan wakil bupati yang sudah dilaksanakan pada tanggal 16 Juni 2012, akan tetapi pada pelaksanaan Pemilukada di Kabupaten Pati ternyata juga membawa dampak negatif. Salah satunya terjadi money politics yang dilakukan oleh tim sukses calon bupati dan wakil bupati kepada masyarakat Kabupaten Pati (KPU Kabupaten Pati, 2015, p. 7).

Adanya fenomena money politics menunjukkan bahwa KPU Kabupaten Pati perlu bekerja secara maksimal untuk mengatasi hal tersebut, sehingga diperlukan pembentukan budaya politik yang partisipatif serta perilaku memilih yang rasional. Sebab, masyarakat di Kabupaten Pati belum sepenuhnya mempunyai budaya politik partisipatif dan perilaku memilih yang rasional. Kondisi tersebut bisa diketahui berdasarkan salah satu hasil penelitian tesis tentang budaya politik yang ada pada masyarakat Samin (Sedulur Sikep) Dukuh Mbombong Desa Baturejo Kecamatan Sukolilo Kabupaten Pati yang memiliki kecenderungan kearah tipe budaya politik subjek-parokial (The parochial-subject political culture). Budaya politik subjek lebih rendah satu derajat dari budaya politik partisipan. Masyarakat dalam tipe budaya ini tetap memiliki pemahaman yang sama sebagai warga negara dan memiliki perhatian terhadap sistem politik, tetapi keterlibatan mereka dalam cara yang lebih pasif. Budaya politik parokial merupakan tipe budaya politik yang paling rendah, mereka tidak memiliki perhatian terhadap apa yang terjadi dalam sistem politik, pengetahuannya sedikit tentang sistem politik, dan jarang membicarakan masalah-masalah politik. Hal ini dapat dipahami dari berbagai hal, salah satunya dapat dilihat dari tingkat pendidikan, masyarakat tidak memiliki tingkat pendidikan yang cukup untuk dapat dan mampu memberikan aksi dan reaksi terhadap sistem politik (masyarakat Samin asli yang tinggal di Dukuh Mbombong Desa Baturejo Kecamatan Sukolilo). Terdapat dua bentuk budaya politik karena masyarakat Samin memiliki dua komunitas masyarakat yakni komunitas masyarakat Samin di luar Dukuh Mbombong dan masyarakat Samin asli yang tinggal di Dukuh Mbombong. Melihat kesederhanaan kehidupan masyarakat Samin, serta ketat dan kuatnya pelaksanaan hukum adat, taat, dan teguhnya keyakinan mereka 
terhadap agama kepercayaannya (agama Adam) serta karakteristik tanah adat yang tidak boleh diubah, ditambah menutup diri dari pengaruh buruk budaya modern, kemudian membayangkan apa mungkin masyarakat Samin berpartisipasi dalam hubungan hidup bermasyarakat dan bernegara (Munadi, 2013, pp.8-9).

Berbicara mengenai perilaku memilih masyarakat di Kabupaten Pati, kondisi tersebut bisa diketahui dari salah satu hasil penelitian skripsi tentang pilihan pemilih terhadap calon anggota DPRD Kabupaten Pati dalam Pemilu Legislatif 2009 di Desa Trangkil Kecamatan Trangkil bahwa ada beberapa faktor yang mempengaruhi pilihan pemilih. Pertama, faktor rasionalitas yaitu pemilih dalam menentukan pilihannya didasarkan pada program yang ditawarkan seorang calon legislatif yang nantinya akan dipilih. Kedua, faktor primordialitas atau ikatan kedaerahan yaitu pemilih menjatuhkan pilihannya kepada seorang kandidat yang berasal dari daerah yang sama dengan pemilih. Ketiga, mitos dan simbol yaitu pemilih tertarik untuk memilih calon legislatif yang memiliki figur karismatik dari sebuah partai politik. Keempat, ikatan emosional yaitu pemilih dalam menentukan pilihannya tidak mudah dipengaruhi dan diubah. Faktor yang kelima adalah money politics, yaitu pemilih dalam memberikan hak suaranya kepada calon legislatif pilihannya karena tertarik dengan materi yang didapatnya dari tim sukses calon legislatif yang dipilihnya tersebut. Sedangkan faktor yang paling berpengaruh dalam mempengaruhi pilihan pemilih adalah faktor primordialitas. Mengenai preferensi terhadap partai politik yang meliputi pemahaman perkembangan partai politik, visi dan misi, profil tokoh-tokoh yang dicalonkan menjadi calon anggota legislatif oleh partai politik serta sosialisasi partai politik ternyata tidak berpengaruh terhadap pilihan pemilih pada calon legislatif dari partai politik yang bersangkutan (Wijayanti, 2009, pp.viii-ix).

Budaya politik merupakan bagian dari kebudayaan masyarakat dengan ciri-ciri yang lebih khas. Istilah budaya politik meliputi masalah legitimasi, pengaturan kekuasaan, proses pembuatan kebijakan pemerintah, kegiatan partai-partai politik, perilaku aparat negara, dan perilaku masyarakat yang berupa partisipasi politik masyarakat dalam kegiatan politik, serta gejolak masyarakat terhadap kekuasaan yang memerintah. Masyarakat dalam melakukan kegiatan politik juga memasuki dunia keagamaan, kegiatan ekonomi, kehidupan pribadi, dan sosial secara luas (Rahman, 2007, p.267). Dengan demikian, budaya politik langsung mempengaruhi kehidupan politik dan menentukan keputusan nasional yang menyangkut pola pengalokasian sumber-sumber masyarakat. Budaya politik juga terdiri dari serangkaian keyakinan, simbol-simbol, dan nilai-nilai yang melatarbelakangi situasi di mana suatu peristiwa politik terjadi (Chilcote, 2007, p.11), sehingga orang-orang yang melibatkan diri dalam kegiatan politik, paling tidak mereka melakukan pemberian suara (voting behavior), dengan cara ikut serta berpartisipasi secara langsung untuk memilih wakil rakyat di daerahnya dalam pemilihan umum kepala daerah.

Pembahasan tentang budaya politik tidak terlepas dari perilaku memilih masyarakat. Perilaku memilih masyarakat pada dasarnya saling berkaitan antara budaya politik yang ada di masyarakat, karena perilaku memilih merupakan sikap masyarakat untuk memberikan suara dan menentukan calon siapa yang akan dipilih menjadi bupati dan wakil bupati dalam Pemilukada secara langsung, sehingga budaya politik yang ada pada masyarakat juga mempengaruhi perilaku memilihnya. Dalam hal ini, masyarakat akan bersikap rasional, bersikap tidak rasional, bersikap acuh tak acuh ataukah masyarakat memang sudah mempunyai kesadaran politik untuk menggunakan hak pilihnya dalam memilih wakil rakyat yang ada di daerahnya ketika diadakan pemilihan umum kepala daerah. Oleh karena itu, adanya perilaku memilih masyarakat dalam Pemilukada merupakan salah satu indikator adanya keterlibatan rakyat dalam kehidupan politik (partisipan). Seperti halnya pada masyarakat Kabupaten Pati yang juga ikut berpartisipasi dalam Pemilukada secara langsung tahun 2012 untuk memilih bupati dan wakil bupati yang diinginkannya. Hal tersebut menunjukkan adanya keterlibatan masyarakat dalam kegiatan politik.

Pada tahun 2004, perilaku memilih masyarakat sudah mengalami perubahan. Antusiasme pemilih (masyarakat) untuk terlibat di dalam Pemilu jauh berkurang. Kalaupun terlibat tidak lepas dari transaksitransaksi material. Tidak sedikit para pemilih, datang ke tempat-tempat kampanye karena 
memperoleh imbalan kaos atau "uang transportasi". Kecenderungan demikian semakin kuat ditemui pada PemilukadaPemilukada yang dilakukan sejak 1 Juni 2005. Transaksi model demikian menghasilkan relasi antara wakil dan terwakil secara terputus, karena transaksi itu selesai ketika (calon) wakil memberikan "materi" dan terwakil menentukan pilihannya (Marijan, 2010, p.131).

Realitas seperti itu mendorong munculnya pandangan 'kalau para wakil memperoleh keuntungan material, mengapa para pemilih tidak?'. Memperoleh kaos dan 'uang transportasi' ketika menghadiri kampanye merupakan bagian dari keuntungan yang berusaha dinikmati oleh para pemilih itu. Di samping itu 'transaksi-transaksi material' juga melihat dari tuntutan sebagian pemilih untuk memperoleh sumbangan dari para wakil. Sejumlah wakil rakyat pernah menyampaikan keluhan ini dalam beberapa workshop yang diselenggarakan oleh Partnership dan forumforum lain yang dihadiri Bapak Kacung Marijan. Mereka mengeluhkan banyaknya sumbangan yang diinginkan oleh konstituen dalam bentuk proposal-proposal (Marijan, 2010, p.131).

Berdasarkan hasil penelitian yang dilakukan Komisi Pemilihan Umum (KPU) Pati dan Sekolah Tinggi Agama Islam Mathali'ul Falah (Staimafa) Pati, didapatkan kesimpulan bahwa penentu kemenangan dalam pesta demokrasi Pemilukada Kabupaten Pati tahun 2012 adalah uang. Riset tersebut mengambil 1.261 orang responden. Sebanyak 670 orang responden atau 53 persen di antaranya adalah laki-laki. Sedangkan responden perempuan sebanyak 591 orang atau 47 persen. Berdasarkan tingkat pendidikan, sebanyak 238 responden $(18,8$ persen) adalah lulusan SD atau sederajat, 276 responden (21,8 persen) berpendidikan SMP atau sederajat, 558 persen (44,2 persen) berpendidikan SMA atau sederajat, 120 responden $(9,5$ persen) berpendidikan $\mathrm{S} 1$, dan 10 responden orang $(0,7$ persen $)$ berpendidikan S2. Sedangkan satu responden lagi $(0,07$ persen) berpendidikan S3. Sikap masyarakat Kabupaten Pati terhadap politik uang bukan menyangkut soal pengetahuan. Bukan juga soal nilai-nilai pendidikan, nilai-nilai agama, dan kepercayaan. Berdasarkan data empiris, faktor kognitif tidak mempunyai korelasi terhadap keputusan pemilih. Sikap masyarakat Kabupaten Pati terhadap politik uang juga bukan karena faktor psikologis dan feeling pemilih. Warga Kabupaten Pati lebih memilih calon yang memberikan uang, ketimbang soal sosok pribadi. Dari hasil penelitian, faktor penentu yang berkorelasi dengan suara pemilih adalah uang (KPU Kabupaten Pati, 2015, pp.7$8)$.

Melihat hasil dari penelitian yang sudah dilakukan KPU Kabupaten Pati pada tahun 2015, maka KPU Kabupaten Pati mempunyai bekal untuk mengurangi praktik politik uang pada Pemilukada mendatang. Ketua KPU Kabupaten Pati, Much. Nasich mengatakan, hasil riset ini akan berguna untuk menyusun program dan strategi pendidikan politik bagi pemilih dalam pemilihan umum kepala daerah secara langsung yang akan datang pada tahun 2017 di Kabupaten Pati (Nasich, Selasa, 2 Februari 2016).

Berdasarkan latar belakang masalah di atas, rumusan masalah yang diangkat dalam penelitian ini adalah: Bagaimana peranan KPU Kabupaten Pati dalam melaksanakan pendidikan politik untuk membentuk budaya politik dan perilaku memilih masyarakat pada Pemilukada serentak di Kabupaten Pati tahun 2017? dan Bagaimana Peranan KPU Kabupaten Pati dalam melaksanakan pendidikan politik bagi masyarakat untuk mengatasi money politics pada Pemilukada serentak di Kabupaten Pati tahun 2017 ?

Di Kabupaten Pati terdapat fenomena politik yang sangat menarik yaitu fenomena budaya politik subjek-parokial pada masyarakat Kabupaten Pati khususnya pada masyarakat Samin Desa Baturejo Kecamatan Sukolilo, serta adanya fenomena perilaku memilih terhadap calon anggota DPRD Kabupaten Pati dalam Pemilu Legislatif 2009 di Desa Trangkil Kecamatan Trangkil yang dipengaruhi oleh faktor rasionalitas, faktor primordialitas atau ikatan kedaerahan, faktor mitos dan simbol, faktor ikatan emosional, dan faktor money politics. Kemudian adanya fenomena money politics ketika Pemilukada tahun 2012 pada masyarakat Kabupaten Pati, sehingga peneliti merasa tertarik untuk meneliti lebih jauh tentang Peranan KPU Kabupaten Pati dalam Pembentukan Budaya Politik dan Perilaku Memilih Masyarakat pada Pemilihan Umum Kepala Daerah Serentak di Kabupaten Pati tahun 2017. 
Berdasarkan latar belakang masalah di atas, penulis tertarik untuk meneliti dan mendeskripsikan lebih dalam mengenai Peranan KPU Kabupaten Pati dalam pembentukan budaya politik dan perilaku memilih masyarakat pada pemilihan umum kepala daerah serentak di Kabupaten Pati tahun 2017.

\section{Metode Penelitian}

Jenis penelitian ini adalah deskriptif dengan pendekatan kualitatif. Jenis deskriptif merupakan penelitian yang prosedur pemecahan masalahnya diselidiki dengan menggambarkan atau melukiskan keadaan subjek atau objek penelitian (seseorang, lembaga, dan masyarakat) pada saat sekarang berdasarkan fakta-fakta yang tampak atau sebagaimana adanya, sehingga penelitian ini mengungkapkan, menggambarkan, dan mendeskripsikan peranan KPU Kabupaten Pati dalam pembentukan budaya politik dan perilaku memilih masyarakat pada pemilihan umum kepala daerah serentak di Kabupaten Pati tahun 2017 (Nawawi, 2007, p. 67).

Setting penelitian menunjukan pada pengertian tempat atau lokasi sosial penelitian yang dirincikan oleh adanya 3 unsur, yaitu: 1) pelaku; 2) tempat; dan 3) kegiatan yang dapat diobservasi. Lokasi atau tempat penelitian di KPU Kabupaten Pati Provinsi Jawa Tengah. Subjek penelitian ini adalah Ketua KPU Kabupaten Pati dan Anggota KPU Kabupaten Pati. Waktu penelitian dilakukan selama 7 bulan, mulai dari tanggal 14 September 2016 sampai dengan 28 Maret 2017.

Dalam penelitian deskriptif unit analisisnya adalah subjek-subjek penelitian yang sudah diwawancarai mengenai peranan KPU Kabupaten Pati dalam pembentukan budaya politik dan perilaku memilih masyarakat pada pemilihan umum kepala daerah serentak di Kabupaten Pati tahun 2017.

Kehadiran peneliti di lapangan sangat diperlukan, karena peneliti sendiri merupakan alat instrumen pengumpul data yang utama (key instrument) yang terjun langsung ke lapangan. Teknik pengambilan sampel dalam penelitian ini adalah menggunakan purposive sampling (teknik sampel bertujuan). Dalam pengunaan purposive sampling peneliti akan mengambil sampel sumber data dengan pertimbangan tertentu, yaitu orang tersebut dianggap paling tahu tentang apa yang diharapkan oleh peneliti, dalam hal ini sumber data penelitian ini adalah: 1) Ketua KPU Kabupaten Pati, yaitu Much. Nasich; 2) Anggota KPU Kabupaten Pati, yaitu Imbang Setiawan (Divisi Sosialisasi dan Pendidikan Pemilih), Supriyanto (Devisi Data dan Informasi), dan Ahmad Jukari (Devisi Pengembangan SDM). Sedangkan jenis data yang digunakan dalam penelitian ini, terdiri dari dua sumber yaitu: data primer dan data sekunder.

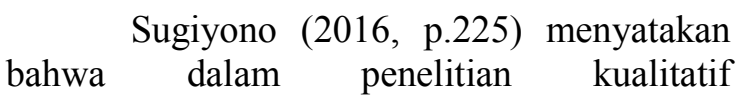
pengumpulan data dilakukan pada natural setting (kondisi yang alamiah). Penelitian ini menggunakan teknik pengumpulan data melalui observasi langsung, wawancara dan dokumentasi.

Triangulasi sumber merupakan teknik keabsahan data yang dianggap relevan untuk menguji keabsahan data dalam penelitian ini. Triangulasi sumber yaitu membandingkan dan mengecek balik derajat kepercayaan suatu informasi yang diperoleh melalui sumber data yang berbeda. Pada penelitian ini, peneliti menggunakan triangulasi sumber untuk mengecek apakah data yang diperoleh dari suatu sumber data yang berbeda dapat menghasilkan data yang sama ketika dibandingkan dengan sumber data yang lain (Moleong, 2014, pp. 330-331). Misalnya, data hasil observasi tentang Peranan KPU dalam pembentukan budaya politik dan perilaku memilih pada Pemilukada Kabupaten Pati 2017 dengan data hasil wawancara yang disampaikan oleh subjek penelitian yaitu Ketua Kabupaten Pati dan Anggota KPU Kabupaten Pati. Peneliti menggunakan observasi partisipatif, wawancara mendalam, dan dokumentasi untuk memastikan kondisi yang sebenarnya di KPU Kabupaten Pati.

Teknik analisis data yang digunakan dalam penelitian ini yaitu reduksi data,kategorisasi dan unitisasi data, display data, pengambilan simpulan dan verifikasi data (Moleong, 2014, p.288).

\section{Hasil Penelitian dan Pembahasan}

Peranan KPU Kabupaten Pati dalam melaksanakan pendidikan politik untuk membentuk budaya politik masyarakat pada Pemilukada serentak di Kabupaten Pati tahun 2017 
Salah satu tujuan dilaksanakannya pendidikan politik oleh KPU Kabupaten Pati adalah untuk membentuk budaya politik partisipan masyarakat pada pemilihan umum kepala daerah serentak di Kabupaten Pati tahun 2017 (Nasich, 7 Maret 2017). Budaya politik yang dimaksud dalam hal ini adalah sebagaimana dijelaskan oleh Almond \& Verba (1984, p.14), yaitu merupakan suatu sikap orientasi yang khas dari warga negara terhadap sistem politik dan aneka ragam bagiannya dan sikap terhadap peranan warga negara di dalam sistem itu. Dengan orientasi ini, mereka menilai serta mempertanyakan tempat-tempat peranan mereka di dalam sistem politik, sedangkan Miriam Budiardjo menyatakan bahwa salah satu aspek penting dalam sistem politik adalah budaya politik yang mencerminkan faktor subjektif. Budaya politik adalah keseluruhan dari pandangan-pandangan politik, seperti norma-norma, pola-pola orientasi terhadap politik, dan pandangan hidup pada umumnya. Budaya politik mengutamakan dimensi psikologis dari suatu sistem politik, yaitu sikap-sikap, sistem-sistem kepercayaan, simbol-simbol yang dimiliki oleh individu-individu, dan beroperasi di dalam seluruh masyarakat, serta harapan-harapannya (Budiardjo, 2008, pp.58-59).

Zamroni (2001, p.25) mengatakan bahwa suatu sistem politik akan bisa langgeng jikalau mendapatkan dukungan dari warga negara masyarakat. Oleh karena itu, bangsa, atau lebih tepatnya penguasa, baik yang memiliki sistem politik kapitalis, komunis, sosialis atau apapun sistem politik yang dianut penguasa tersebut, perlu melaksanakan sosialisasi politik, khususnya dikalangan masyarakat secara umum. Hal ini bertujuan agar mereka memiliki pengetahuan politik, kesadaran politik, nilai, sikap dan orientasi politik; dan mampu berpartisipasi dalam politik, sehingga aktif memberi dukungan dan kelak bisa melanggengkan sistem politik yang dianut selama ini. Tanpa adanya keberhasilan dalam sosialisasi politik akan muncul gejolak politik yang berkepanjangan yang merupakan pencerminan tidak adanya dukungan warga masyarakat terhadap sistem politik yang ada, yang akan membawa akibat sistem politik runtuh atau diganti.

Dari pendapat Zamroni di atas terlihat bahwa tujuan dari sosialisasi politik atau pendidikan politik adalah masyarakat secara umum memiliki: (1) pengetahuan politik; (2) kesadaran politik; (3) nilai, sikap, dan orientasi politik, dan (4) mampu berpartisipasi politik. Kesemua tujuan tadi bermuara untuk mendidik warga negara yang aktif memberi dukungan dalam melanggengkan sistem politik yang dianut selama ini. Seperti halnya KPU Kabupaten Pati, tujuan yang ingin dicapai dalam melaksanakan sosialisasi politik dan pendidikan politik tidak jauh berbeda dengan pendapat Zamroni, bahwa sosialisasi politik dan pendidikan politik yang ingin dicapai oleh KPU Kabupaten Pati adalah untuk memberikan informasi secara prosedural seperti tahapan-tahapan pemilukada dan teknis pemilukada tetapi juga bertujuan untuk membangun pengetahuan politik, menumbuhkan kesadaran politik, meningkatkan partisipasi politik serta memberikan pendidikan politik supaya terbentuk budaya politik partisipan dan perilaku memilih rasional pada masyarakat Kabupaten Pati (Nasich \& Setiawan, 7 Maret 2017). Pendidikan politik yang berlandaskan pada Pancasila dan UUD 1945 berfungsi mengembangkan kemampuan dan membentuk watak serta peradaban bangsa yang bermartabat dalam rangka mencerdaskan kehidupan bangsa yang bertujuan untuk berkembangnya potensi setiap warga negara agar menjadi manusia yang beriman dan bertaqwa kepada Tuhan Yang Maha Esa, berakhlak mulia, jujur, dan menjadi warga negara yang demokratis serta bertanggungjawab dalam melaksanakan kehidupan politik sehari-hari (Christopel \& Kuntoro, 2016, p.15).

Terdapat banyak kegiatan sosialisasi politik dan pendidikan politik yang sudah dilaksanakan oleh KPU Kabupaten Pati yang bertujuan untuk menyebarluaskan informasi mengenai tahapan, program, dan jadwal pemilihan, meningkatkan pengetahuan, pemahaman dan kesadaran masyarakat tentang hak dan kewajiban dalam pemilihan, meningkatkan partisipasi pemilih dalam pemilihan, serta untuk membentuk budaya politik dan perilaku memilih masyarakat Kabupaten Pati pada pemilihan umum kepala daerah serentak di Kabupaten Pati tahun 2017 (Setiawan, 7 Maret 2017). Peneliti sendiri sudah melaksanakan observasi secara langsung sebanyak 12 kali pada kegiatan sosialisasi politik dan pendidikan politik yang sudah dilaksanakan oleh KPU Kabupaten Pati. Kegiatan sosialisasi politik dan pendidikan 
politik tersebut dilaksanakan dengan metode komunikasi tatap muka secara langsung dengan masyarakat Kabupaten Pati melalui program diskusi, seminar, workshop, rapat kerja, pelatihan, ceramah, dan simulasi. Sasaran sosialisasi politik dan pendidikan politik yang dilaksanakan oleh KPU Kabupaten Pati adalah semua masyarakat Kabupaten Pati yang sudah dewasa (berusia 17 tahun dan/sudah menikah), mempunyai KTP/eKTP, mempunyai hak pilih serta tidak terganggu jiwanya. Sasaran dalam pelaksanaan sosialisasi pemilihan, meliputi masyarakat umum; yang terdiri dari pemilih pemula meliputi remaja, pemuda, pelajar dan mahasiswa; tokoh masyarakat dan/atau pemuka adat; kelompok media massa; partai politik; pengawas pemilihan, Pemantau Pemilihan Dalam Negeri dan Pemantau Pemilihan Asing; organisasi kemasyarakatan; organisasi keagamaan; kelompok adat; instansi pemerintah; dan/atau; pemilih dengan kebutuhan khusus. Pemilih dengan kebutuhan khusus sebagaimana dimaksud mencakup penyandang disabilitas, masyarakat di wilayah perbatasan atau terpencil, penghuni lembaga permasyarakatan, pasien dan pekerja rumah sakit, pekerja tambang lepas pantai, perkebunan, dan kelompok lain yang terpinggirkan (Setiawan, Nasich, Jukari, \& Supriyanto, 7 Maret 2017).

Orientasi kognitif budaya politik

KPU Kabupaten Pati dalam melaksanakan kegiatan pendidikan politik untuk membentuk budaya politik masyarakat mempunyai tujuan supaya terbentuk budaya politik partisipatif (partisipan) karena budaya politik ini yang akan mendukung terbentuknya sebuah sistem politik yang demokratik dan stabil (Nasich \& Setiawan, 7 Maret 2017), selain itu dalam budaya politik partisipan menyangkut suatu kumpulan keyakinan, sikap, norma, persepsi, dan sejenisnya yang menopang terwujudnya partisipasi (Gaffar, 2006, p.101).

Dalam pendekatan perilaku politik, terdapat interaksi antara manusia satu dengan lainnya yang akan selalu terkait dengan pengetahuan, sikap, dan nilai seseorang yang kemudian memunculkan orientasi sehingga timbul budaya politik. Orientasi politik itulah yang kemudian membentuk tatanan di mana interaksi-interaksi yang muncul tersebut akhirnya mempengaruhi budaya politik seseorang. Orientasi politik tersebut dapat dipengaruhi oleh orientasi individu dalam memandang objek-objek politik. Almond \& Verba (1984, p.16) mengajukan klasifikasi tipe-tipe orientasi politik, yaitu orientasi kognitif, orientasi afektif, dan orientasi evaluatif. Orientasi kognitif budaya politik, yaitu kemampuan yang menyangkut tingkat pengetahuan dan pemahaman serta kepercayaan dan keyakinan individu terhadap jalannya sistem politik dan atributnya, seperti tokoh-tokoh pemerintahan, kebijaksanaan yang mereka ambil, atau mengenai simbol-simbol negara seperti lambang negara.

Perlu disadari bahwa dalam realitas kehidupan, ketiga komponen ini tidak terpilahpilah tetapi saling terkait atau sekurangkurangnya saling mempengaruhi. Semisal seorang warga negara dalam melaksanakan penilaian terhadap seorang pemimpin, ia harus mempunyai pengetahuan yang memadai tentang si pemimpin. Pengetahuan itu tentu saja sudah dipengaruhi, diwarnai, atau dibentuk oleh perasaannya sendiri. Sebaliknya, pengetahuan orang tersebut tentang sesuatu simbol politik, misalnya, dapat pula membentuk atau mewarnai perasaannya terhadap simbol politik itu. Boleh jadi, pengetahuan tentang suatu simbol sering mempengaruhi perasaan seseorang terhadap sistem politik secara keseluruhan (Alfian \& Sjamsuddin, 1991, p.22). KPU Kabupaten Pati dalam melaksanakan pendidikan politik untuk membentuk budaya politik masyarakat Kabupaten Pati, pada materi yang disampaikan kepada masyarakat Kabupaten Pati tentu memperhatikan orientasi budaya politik yaitu orientasi kognitif, orientasi afektif, dan orientasi evaluatif, sehingga pada pembahasan ini akan terlebih dahulu dipaparkan mengenai orientasi kognitif yang terdapat dalam materi pendidikan politik yang dilaksanakan oleh KPU Kabupaten Pati pada pemilihan umum kepala daerah serentak di Kabupaten Pati tahun 2017 (Nasich \& Setiawan, 7 Maret 2017)

KPU Kabupaten Pati ketika melaksanakan kegiatan pendidikan politik kepada masyarakat Kabupaten Pati berusaha mengembangkan orientasi kognitif masyarakat Kabupaten Pati dengan cara memberikan materi yang mengandung orientasi kognitif berupa pengetahuan dan pemahaman serta kepercayaan dan keyakinan individu terhadap jalannya sistem politik dan atributnya, seperti meyakinkan masyarakat supaya menggunakan 
hak pilihnya pada pemilukada, menegasakan kepada masyarakat supaya tidak golput, memberikan informasi mengenai tata cara pencoblosan, memberikan informasi mengenai siapa saja calon bupati dan wakil bupati pada Pemilukada Kabupaten Pati tahun 2017, memberikan informasi mengenai kapan dilaksanakannya Pemilukada Kabupaten Pati tahun 2017. KPU Kabupaten Pati meyakini bahwa warga negara yang cerdas dalam artian mempunyai pengetahuan politik merupakan salah satu modal utama dalam pembentukan budaya politik partisipan (Nasich \& Setiawan, 7 Maret 2017).

Orientasi afektif budaya politik

Dalam pendekatan perilaku politik, terdapat interaksi antara manusia satu dengan lainnya yang akan selalu terkait dengan pengetahuan, sikap, dan nilai seseorang yang kemudian memunculkan orientasi sehingga timbul budaya politik. Orientasi politik itulah yang kemudian membentuk tatanan di mana interaksi-interaksi yang muncul tersebut akhirnya mempengaruhi budaya politik seseorang. Orientasi politik tersebut dapat dipengaruhi oleh orientasi individu dalam memandang objek-objek politik. Almond dan Verba (1984, p.16) mengajukan klasifikasi tipe-tipe orientasi politik, yaitu orientasi kognitif, orientasi afektif, dan orientasi evaluatif. Orientasi afektif dalam budaya politik, yaitu menyangkut perasaan seorang warga negara terhadap sistem politik dan peranannya yang dapat membuatnya menerima atau menolak sistem politik yang berlaku di negaranya, sehingga pada pembahasan kali ini adalah mengenai materi pengetahuan politik tentang orientasi afektif dalam budaya politik yang sudah diberikan oleh KPU Kabupaten Pati kepada masyarakat ketika melaksanakan kegiatan sosialisasi politik dan pendidikan politik untuk membentuk budaya politik partisipan masyarakat pada Pemilukada serentak di Kabupaten Pati tahun 2017.

KPU Kabupaten Pati dalam melaksanakan kegiatan sosialisasi politik dan pendidikan politik menegaskan bahwa setiap warga negara harus menggunakan hak pilihnya karena mereka berstatus sebagai warga negara dari suatu negara yaitu Negara Indonesia. Materi pengetahuan politik tersebut disampaikan pada 12 kegiatan sosialisasi politik dan pendidikan politik yang sudah dilaksanakan oleh KPU Kabupaten Pati. Materi ini penting untuk ditegaskan kepada pemilih bahwa mereka adalah warga negara dari Negara Indonesia yang mempunyai hak dan kewajiban terhadap negaranya. Salah satu hak warga negara adalah menggunakan hak pilihnya pada Pemilukada serentak yang jatuh pada hari Rabu tanggal 15 Februari 2017. Warga negara yang menggunakan hak pilihnya merupakan bagian dari orientasi afektif yang menyangkut perasaan sebagai seorang warga negara terhadap sistem politik dan peranannya, yang dapat membuatnya menerima atau menolak sistem politik yang berlaku di negaranya, sehingga warga negara yang menggunakan hak pilihnya merupakan salah satu cara untuk menerima sistem politik serta ikut mengambil peranan dalam sistem politik yang berlaku di negaranya (Much. Nasich, 8 Maret 2017).

\section{Orientasi evaluatif budaya politik}

Pada hakekatnya kebudayaan politik suatu masyarakat terdiri dari sistem kepercayaan yang sifatnya empiris, simbolsimbol yang ekspresif, dan sejumlah nilai yang membatasi tindakan-tindakan politik, maka kebudayaan politik selalu menyediakan arah dan orientasi subjektif bagi politik. Karena kebudayaan politik merupakan salah satu aspek dari kehidupan politik, maka jika kita ingin mendapatkan gambaran dan ciri politik suatu kelompok masyarakat secara bulat dan utuh, maka kita pun dituntut melaksanakan penelaahan terhadap sisinya yang lain (Alfian \& Sjamsuddin, 1991, p.23).

Berkaitan dengan sistem politik, kebudayaan politik masyarakat dipengaruhi oleh sejarah perkembangan sistem, di samping itu kebudayaan politik lebih mengutamakan dimensi psikologis suatu sistem, seperti sikap, sistem kepercayaan, atau simbol-simbol yang dimiliki dan diterapkan oleh individu-individu dalam suatu masyarakat sekaligus harapanharapannya. Variabel yang ada bisa berawal dari suasana psikologis seseorang, argumentasi umum dalam jajaran psikologi sosial, dan terminal terakhir bertumpu pada status sosialekonomi yang dimiliki oleh seseorang atau sekolompok orang sebagai determinan pembentukan orientasi, sikap, dan tingkah laku politik (Alfian \& Sjamsuddin, 1991, p.24).

Orientasi politik tersebut dapat dipengaruhi oleh orientasi individu dalam memandang objek-objek politik. Almond \& Verba (1984, p.16) mengajukan klasifikasi tipe-tipe orientasi politik, yaitu orientasi kognitif, orientasi afektif, dan orientasi 
evaluatif. Orientasi evaluatif budaya politik yaitu menyangkut keputusan dan praduga tentang objek-objek politik yang secara tipikal melibatkan kombinasi standar nilai dan kriteria dengan informasi dan perasaan, sehingga pada pembahasan kali ini adalah mengenai materi tentang orientasi evaluatif dalam budaya politik yang sudah diberikan oleh KPU Kabupaten Pati kepada masyarakat ketika melaksanakan kegiatan sosialisasi politik dan pendidikan politik untuk membentuk budaya politik partisipan masyarakat pada Pemilukada serentak di Kabupaten Pati tahun 2017.

KPU Kabupaten Pati dalam melaksanakan kegiatan sosialisasi politik dan pendidikan politik menegaskan bahwa setiap warga negara mempunyai hak untuk diikutsertakan dalam proses pembuatan/penentuan kebijakan yang dilaksanakan oleh Pemerintah Daerah Kabupaten Pati. Misalnya masyarakat mengikuti acara temu bupati dan wakil bupati atau acara pertemuan di Kecamatan dan Desa untuk menyampaikan saran dan kritik yang membangun. Materi pengetahuan politik tersebut disampaikan pada 4 kegiatan sosialisasi politik dan pendidikan politik yang sudah dilaksanakan oleh KPU Kabupaten Pati, yaitu pada kegiatan "Sosialisasi Pemilihan Bupati dan Wakil Bupati Pati Tahun 2017 Kepada Pemilih Perempuan Menuju Terwujudnya Pemilihan yang Berintegritas dan Bermartabat", "Sosialisasi Pemilihan Bupati dan Wakil Bupati Pati Tahun 2017 Bagi Kelompok Pemilih Pemula", "Sosialisasi Pemilihan Bupati dan Wakil Bupati Pati Tahun 2017 "Launching Naskah Khutbah Jum'at" Kerjasama KPU Kabupaten Pati dan Pimpinan Daerah Muhammadiyah Kabupaten Pati”, "Sosialisasi dan Launching Buku Khutbah Pemilihan Bupati dan Wakil Bupati Pati Tahun 2017, Bersama: Da'i LDNU Se-Kabupaten Pati”, akan tetapi ketika melaksanakan 8 kegiatan sosialisasi politik dan pendidikan politik selain 4 kegiatan yang sudah disebutkan di atas, KPU Kabupaten Pati tidak menegaskan atau tidak memberikan materi pengetahuan politik bahwa setiap warga negara mempunyai hak untuk diikutsertakan dalam proses pembuatan/penentuan kebijakan yang dilaksanakan oleh Pemerintah Daerah Kabupaten Pati.

Alasan KPU Kabupaten Pati tidak memberikan materi pengetahuan politik tersebut dikarenakan adanaya keterbatasan
SDM, keterbatasan waktu serta disesuaikan dengan sasaran pelaksanaan sosialisasi politik dan pendidikan politik misalnya pada temanteman difabel yang mempunyai keterbatasan fisik serta warga binaan yang tinggal di lapas tentu kurang tepat jika mengajak mereka supaya aktif diikutsertakan dalam proses pembuatan/penentuan kebijakan yang dilaksanakan oleh pemerintah daerah Kabupaten Pati (Setiawan, 8 Maret 2017).

Peranan KPU dalam melaksanakan pendidikan politik untuk membentuk perilaku memilih masyarakat pada Pemilukada serentak di Kabupaten Pati tahun 2017

Terdapat banyak kegiatan sosialisasi politik dan pendidikan politik yang sudah dilaksanakan oleh KPU Kabupaten Pati yang bertujuan untuk menyebarluaskan informasi mengenai tahapan, program, dan jadwal pemilihan, meningkatkan pengetahuan, pemahaman dan kesadaran masyarakat tentang hak dan kewajiban dalam pemilihan, meningkatkan partisipasi pemilih dalam pemilihan, serta untuk membentuk perilaku memilih rmasyarakat Kabupaten Pati pada pemilihan umum kepala daerah serentak di Kabupaten Pati tahun 2017 (Setiawan, 13 April 2017). Peneliti sendiri sudah melaksanakan observasi secara langsung sebanyak 12 kali pada kegiatan sosialisasi politik dan pendidikan politik yang sudah dilaksanakan oleh KPU Kabupaten Pati untuk membentuk perilaku memilih masyarakat pada Pemilukada serentak di Kabupaten Pati tahun 2017.

Untuk memahami perilaku memilih masyarakat yang dibentuk oleh KPU Kabupaten Pati pada Pemilukada serentak di Kabupaten Pati tahun 2017, dalam penelitian ini peneliti menggunakan tiga pendekatan yaitu pendekatan sosiologis, pendekatan psikologis, dan pendekatan rasional. Pada pendekatan sosiologis masyarakat memilih calon bupati dan wakil bupati dikarenakan faktor-faktor sosial misalnya memilih dikarenakan kesamaan agama, suku atau golongan, pekerjaan, jenis kelamin, pendidikan, dan status sosial yang ada di masyarakat (Asfar, 2006, p.138), sedangkan pada pendekatan psikologis masyarakat memilih calon bupati dan wakil bupati dikarenakan tiga aspek utama yaitu, ikatan emosional pada suatu partai politik, orientasi terhadap isu-isu, dan orientasi terhadap kandidat (Niemi \& Weisberg, 1984, 
pp.12-13). Kemudian pada pendekatan rasional, masyarakat memilih calon bupati dan wakil bupati dikarenakan masyarakat bertindak rasional, yaitu menekan ongkos sekecilkecilnya untuk memperoleh keuntungan sebesar-besarnya. Maka dalam perilaku memilih rasional (rational choice), pemilih bertindak rasional yaitu memilih kandidat atau partai politik yang dianggap mendatangkan keuntungan yang sebesar-besarnya dan menekan kerugian sekecil-kecilnya (Cholisin \& Nasiwan, 2012, p.153). Para para pemilih rasional diasumsikan mempunyai kemampuan untuk menilai isu-isu politik yang ditujukan kepada para kandidat dalam pemilukada. Penilaian rasional terhadap isu politik yang ditujukan kepada para kandidat pemilukada dapat berupa jabatan, informasi pekerjaan, informasi kepribadian, rekam jejak pribadi yang popular karena prestasi di bidangnya masing-masing seperti seni, olahraga, film, organisasi politik, dan semacamnya.

Pendekatan sosiologis perilaku memilih

KPU Kabupaten Pati ketika melaksanakan kegiatan sosialisasi politik dan pendidikan politik kepada masyarakat Kabupaten Pati memberikan materi pengetahuan politik supaya masyarakat bisa memilih pasangan calon bupati dan wakil bupati karena alasan tingkat pendidikan yang tinggi dari salah satu pasangan calon bupati dan wakil bupati. KPU Kabupaten Pati dalam melaksanakan kegiatan sosialisasi politik dan pendidikan politik kepada masyarakat Kabupaten Pati jarang memberikan materi pengetahuan politik tentang kesaamaan agama, suku, kesamaan organisasi politik serta kesamaan organisasi masyarakat bisa dijadikan sebagai bahan pertimbangan untuk memilih calon bupati dan wakil bupati pada Pemilihan Umum Kepala Daerah serentak di Kabupaten Pati tahun 2017.

Pendekatan psikologis perilaku memilih

KPU Kabupaten Pati dalam melaksanakan kegiatan sosialisasi politik dan pendidikan politik kepada masyarakat Kabupaten Pati memberikan materi pengetahuan politik supaya sikap masyarakat yang terbentuk oleh organisasi (LSM, Partai Politik) yang mereka ikuti juga bisa dijadikan bahan pertimbangan untuk memilih calon bupati dan calon wakil bupati Pati. Materi pengetahuan politik tersebut disampaikan pada 3 kegiatan sosialisasi politik dan pendidikan politik yang sudah dilaksanakan oleh KPU
Kabupaten Pati, yaitu pada kegiatan "Sosialisasi Pemilihan Bupati dan Wakil Bupati Pati Tahun 2017 Kepada Pemilih Perempuan Menuju Terwujudnya Pemilihan yang Berintegritas dan Bermartabat", "Sosialisasi Pemilihan Bupati dan Wakil Bupati Pati Tahun 2017 "Launching Naskah Khutbah Jum'at" Kerjasama KPU Kabupaten Pati dan Pimpinan Daerah Muhammadiyah Kabupaten Pati", "Sosialisasi dan Launching Buku Khutbah Pemilihan Bupati dan Wakil Bupati Pati Tahun 2017, Bersama: Da'i LDNU Se-Kabupaten Pati", akan tetapi ketika melaksanakan 9 kegiatan sosialisasi politik dan pendidikan politik selain 3 kegiatan yang sudah disebutkan di atas, KPU Kabupaten Pati tidak memberikan materi supaya sikap masyarakat yang terbentuk oleh organisasi (LSM, Partai Politik) yang mereka ikuti juga bisa dijadikan bahan pertimbangan untuk memilih calon bupati dan calon wakil bupati Pati. Alasan KPU Kabupaten Pati menyampaikan materi pengetahuan politik tersebut hanya pada 3 kegiatan pendidikan politik yaitu pendidikan politik kepada pemilih perempuan yang terdiri dari anggota Muslimat Fatayat NU, Aisyiah Muhammadiyah, Persit Kartika Chandra Kirana, Bhayangkari, PKK Kabupaten Pati dll, pendidikan politik kepada warga NU serta warga Muhammadiyah sebab mereka merupakan anggota dari organisasi masyarakat yang diikuti sehingga tepat jika sikap mereka yang terbentuk oleh organisasi masyarakat yang diikuti bisa dijadikan sebagai bahan pertimbangan untuk memilih bupati dan wakil bupati Pati tahun 2017 (Supriyanto, 13 April 2017).

Pendekatan rasional perilaku memilih

KPU Kabupaten Pati dalam melaksanakan kegiatan sosialisasi politik dan pendidikan politik kepada masyarakat Kabupaten Pati memberikan materi pengetahuan politik serta menegaskan supaya masyarakat memilih salah satu pasangan calon bupati dan wakil bupati pada Pemilukada yang tidak melaksanakan money politics atau memilih bukan dikarenakan money politics. Materi tersebut disampaikan pada 12 kegiatan sosialisasi politik dan pendidikan politik yang sudah dilaksanakan oleh KPU Kabupaten Pati yang telah diobservasi peneliti. Alasan KPU Kabupaten Pati menyampaikan materi pengetahuan politik tersebut dikarenakan money politics itu sangat merugikan masyarakat, bangsa, dan negara serta calon 
bupati dan wakil bupati yang melakukan money politics, selain itu juga menimbulkan dampak negatif bagi masa depan berlangsungnya sistem politik yang ada pada suatu negara yaitu adanya korupsi/KKN, sehingga materi pengetahuan politik ini perlu disampaikan kepada masyarakat Kabupaten Pati supaya terwujud pemilihan umum kepala daerah serentak yang baik, jujur, transparan, bermartabat, dan berintegritas. KPU Kabupaten Pati juga berharap supaya masyarakat memilih calon bupati dan wakil bupati yang jujur serta tidak melakukan money politics supaya Kabupaten Pati mempunyai pemimpin yang jujur, amanah serta bertanggungjawab dalam mengemban tugasnya (Setiawan, 13 April 2017).

KPU Kabupaten Pati dalam melaksanakan kegiatan sosialisasi politik dan pendidikan politik kepada masyarakat Kabupaten Pati memberikan materi pengetahuan politik supaya masyarakat memilih salah satu pasangan calon bupati dan wakil bupati pada Pemilukada dikarenakan program-program/visi misi yang ditawarkan oleh calon bupati dan wakil bupati yang akan dipilih itu, program-programnya menarik, sesuai kepentingan masyarakat, dan bisa membawa perubahan ke arah yang lebih baik bagi masyarakat Kabupaten Pati. Materi tersebut disampaikan pada 12 kegiatan sosialisasi politik dan pendidikan politik yang sudah dilaksanakan oleh KPU Kabupaten Pati yang sudah diobservasi peneliti. Alasan KPU Kabupaten Pati menyampaikan materi pengetahuan politik tersebut dikarenakan memilih calon bupati dan wakil bupati karena visi dan misinya, merupakan suatu hal yang sangat penting untuk dilaksanakan. Visi dan misi itu, ibarat program kerja jangka pendek dan jangka panjang yang ingin dicapai oleh bupati dan wakil bupati beserta jajaran pemerintahan di Kabupaten Pati yang bertujuan untuk kemakmuran dan kesejahteraan masyarakat Kabupaten Pati sesuai dengan semboyan Pati Bumi Mina Tani. Memilih calon bupati dan wakil bupati dikarenakan visi dan misinya, merupakan salah satu indikator adanya perilaku memilih rasional dan budaya politik partisipan di masyarakat, selain itu dengan adanya visi dan misi yang jelas maka masyarakat bisa memantau kinerja Pemerintah Daerah Kabupaten Pati, apakah kinerjanya tersebut sesuai dengan visi dan misi serta kepentingan masyarakat Kabupaten Pati ataukah hanya sesuai dengan kepentingan segelintir orang atau kelompok tertentu (Supriyanto, 13 April 2017).

KPU Kabupaten Pati dalam melaksanakan kegiatan pendidikan politik kepada masyarakat Kabupaten Pati memberikan materi supaya masyarakat memilih salah satu pasangan calon bupati dan wakil bupati pada Pemilukada dikarenakan kepribadian/figur/akhlak dari calon bupati dan calon wakil bupati Pati. Materi tersebut disampaikan pada 12 kegiatan pendidikan politik yang sudah dilaksanakan oleh KPU Kabupaten Pati. Alasan KPU Kabupaten Pati menyampaikan materi pengetahuan politik tersebut pada 12 kegiatan pendidikan politik yang sudah dilaksanakan KPU Kabupaten Pati karena salah satu indikator perilaku memilih rasional adalah memilih calon bupati dan wakil bupati Kabupaten Pati dikarenakan kepribadian/figur/akhlaknya sebab pemimpin yang mempunyai kepribadian baik diharapkan dapat mengemban amanah dari masyarakat yang sudah memilihnya dengan penuh tanggungjawab, jujur, transparan, dan responsif, sehingga visi dan misi yang dijanjikan oleh calon bupati dan wakil bupati yang sudah terpilih dapat diwujudkan sesuai dengan harapan masyarakat yang sudah memilihnya (Jukari, 13 April 2017).

KPU Kabupaten Pati dalam melaksanakan 12 kegiatan sosialisasi politik dan pendidikan politik yang sudah diobservasi peneliti, KPU tidak memberikan materi pengetahuan politik supaya masyarakat memilih salah satu pasangan calon bupati dan wakil bupati pada Pemilukada dikarenakan tingkat kesisteman partai politik yang diusung oleh calon yang akan dipilih juga bisa dijadikan bahan pertimbangan untuk memilih misalnya dalam penyelesaian konflik, pembuatan keputusan, dan dalam membina hubungan dengan simpatisannya. Alasan KPU Kabupaten Pati tidak menyampaikan materi pengetahuan politik tersebut dikarenakan terbatasnya waktu untuk menyampaikan materi pengetahuan politik tersebut serta terbatasnya SDM dari pihak KPU yang ikut terlibat dalam kegiatan pendidikan politik, selain itu KPU lebih menekankan kepada masyarakat supaya memilih calon bupati dan wakil bupati dikarenakan kepribadian dan rekam jejaknya dalam kehidupan politik dan kehidupan sosial masyarakat sehari-hari sebab apapun partai 
politiknya selama calon bupati dan wakil bupati tersebut mempunyai kepribadian dan rekam jejak yang baik maka mereka layak untuk dipilih (Supriyanto, 13 April 2017).

$$
\text { KPU Kabupaten Pati dalam }
$$

melaksanakan 12 kegiatan sosialisasi politik dan pendidikan politik yang sudah diobservasi peneliti, KPU tidak memberikan materi pengetahuan politik supaya masyarakat memilih salah satu pasangan calon bupati dan wakil bupati pada Pemilukada dikarenakan partai politik yang mewakili/mengusung calon yang akan dipilih sesuai dengan apa yang diketahui masyarakat (misalnya, partai tersebut jujur dan tidak korupsi) juga bisa dijadikan bahan pertimbangan untuk memilih. Alasan KPU Kabupaten Pati tidak menyampaikan materi pengetahuan politik tersebut dikarenakan terbatasnya waktu untuk menyampaikan materi pengetahuan politik tersebut serta terbatasnya SDM dari pihak KPU yang ikut terlibat dalam kegiatan pendidikan politik, selain itu KPU lebih menekankan kepada masyarakat supaya memilih calon bupati dan wakil bupati dikarenakan kepribadian dan rekam jejaknya dalam kehidupan politik dan kehidupan sosial masyarakat sehari-hari sebab apapun partai politiknya selama calon bupati dan wakil bupati tersebut mempunyai kepribadian dan rekam jejak yang baik maka mereka layak untuk dipilih. KPU Kabupaten Pati juga menekankan supaya masyarakat memilih calon bupati dan wakil bupati karena program kerjanya atau visi dan misi yang diusung untuk masa kerja 5 tahun yang akan datang (Supriyanto, 13 April 2017).

KPU Kabupaten Pati dalam melaksanakan kegiatan sosialisasi politik dan pendidikan politik kepada masyarakat Kabupaten Pati memberikan materi pengetahuan politik supaya masyarakat memilih salah satu pasangan calon bupati dan wakil bupati pada Pemilukada dikarenakan mempunyai kedekatan secara pribadi (sudah mengenal kepribadian/karakter) dengan salah satu pasangan calon bupati dan wakil bupati, dalam hal ini masyarakat sudah mengenal dengan dekat sosok pasangan calon bupati dan wakil bupati yang akan dipilih tersebut (track record/rekam jejak dalam kegiatan sosial, politik, dan masyarakat). Materi pengetahuan politik tersebut disampaikan pada 12 kegiatan pendidikan politik yang sudah diobservasi peneliti. Alasan KPU Kabupaten Pati memberikan materi pengetahuan politik tersebut supaya masyarakat tidak salah memilih calon bupati dan wakil bupati sehingga mereka memilih berdasarkan kepribadian/karakter serta memilih karena track record/rekam jejak/prestasi dari sang calon bupati dan wakil bupati. Harapannya bupati dan wakil bupati yang terpilih dapat melaksanakan amanahnya dengan penuh tanggungjawab, jujur, transparan, dan responsif, sehingga bupati dan wakil bupati yang terpilih dapat melaksanakan program kerjanya atau visi dan misi yang diusung untuk masa kerja 5 tahun yang akan datang supaya terwujud kemajuan dan kesejahteraan bagi masyarakat Kabupaten Pati sesuai dengan slogan Pati Bumi Mina Tani (Supriyanto, 13 April 2017).

Peranan KPU dalam melaksanakan pendidikan politik untuk mengatasi money politics pada Pemilukada serentak di Kabupaten Pati tahun 2017

KPU Kabupaten Pati dalam melaksanakan kegiatan pendidikan politik, tentu mempunyai tujuan yang ingin dicapai. Seperti yang tertuang dalam pedoman teknis tentang sosialisasi dan partisipasi masyarakat dalam pemilihan bupati dan wakil bupati Pati tahun 2017 yang diatur dalam keputusan Komisi Pemilihan Umum Kabupaten Pati Nomor: $\quad 07 / K p t s / K P U-$ Kab.012.329311/V/2016. Sosialisasi politik dan pendidikan politik yang dilaksanakan oleh KPU Kabupaten Pati bertujuan, tidak hanya memberikan informasi secara prosedural seperti tahapan-tahapan pemilukada dan teknis pemilukada tetapi juga bertujuan untuk membangun pengetahuan politik, menumbuhkan kesadaran politik, meningkatkan partisipasi politik serta untuk mengatasi money politics pada Pemilukada serentak di Kabupaten Pati tahun 2017 (Nasich \& Setiawan, 13 April 2017).

Terdapat banyak program kegiatan sosialisasi politik dan pendidikan politik yang telah dilaksanakan oleh KPU Kabupaten Pati untuk mengatasi money politics pada Pemilukada serentak Kabupaten Pati tahun 2017, namun karena keterbatasan waktu, tenaga, dan akomodasi dari peneliti sendiri maka peneliti hanya melaksanakan observasi sebanyak 12 kali pada program kegiatan sosialisasi politik dan pendidikan politik KPU 
Kabupaten Pati pada Pemilukada serentak di Kabupaten Pati tahun 2017.

Kegiatan pendidikan politik yang telah dilaksanakan oleh KPU Kabupaten Pati untuk mengatasi money politics pada Pemilukada serentak di Kabupaten Pati tahun 2017 dilakukan dengan cara KPU Kabupaten Pati memberikan materi pengetahuan politik tentang bahaya atau dampak negatif money politics, KPU Kabupaten Pati menekankan dan menegaskan kepada masyarakat supaya tidak memilih calon bupati dan wakil bupati yang melakukan money politics dan tidak memilih calon bupati dan wakil bupati karena money politics, KPU Kabupaten Pati memberikan materi pengetahuan politik tentang dampak positif atau manfaat Pemilukada yang sehat dan bersih kepada masyarakat, KPU Kabupaten Pati menegaskan dan menekankan kepada masyarakat untuk bersama-sama atau saling bekerjasama mengawal Pemilukada yang jujur dan sehat, KPU Kabupaten Pati memberikan materi pengetahuan politik tentang bagaimana prosedur yang harus dilaksanakan masyarakat ketika ada calon bupati dan calon wakil bupati yang melakukan money politics atau kecurangan lainnya seperti berkampanye di tempat yang dilarang untuk kampanye. Kegiatan pendidikan politik tersebut dilaksanakan dengan metode komunikasi tatap muka secara langsung dengan masyarakat Kabupaten Pati melalui program diskusi, seminar, workshop, rapat kerja, pelatihan, ceramah, dan simulasi, sedangkan pendidikan politik secara tidak langsung dilaksanakan KPU Kabupaten Pati melalui kegiatan memberikan informasi atau talkshow melalui siaran radio dan televisi dan memberikan informasi melalui media dalam jaringan (online) yaitu melalui FB, Twitter, dan Website KPU Kabupaten Pati (Nasich, Setiawan, Jukari, \& Supriyanto, 13 April 2017).

\section{Simpulan dan Saran}

Simpulan

KPU Kabupaten Pati dapat ditarik kesimpulan bahwa KPU Kabupaten Pati telah melaksanakan peranan untuk membentuk budaya politik, membentuk perilaku memilih dan mengatasi money politics pada Pemilukada serentak di Kabupaten Pati tahun 2017 melalui pelbagai program sosialisasi politik dan pendidikan politik kepada masyarakat Kabupaten Pati yang dilakukan dengan cara memberikan materi pengetahuan politik tentang budaya politik, perilaku memilih, dan money politics yang disampaikan dengan metode ceramah, diskusi, simulasi, seminar, workshop, dan pelatihan.

KPU Kabupaten Pati dalam melaksanakan sosialisasi politik dan pendidikan politik untuk membentuk budaya politik terfokus pada pembentukan orientasi kognitif (pengetahuan) budaya politik, sedangkan pembentukan orientasi afektif (perasaan) dan orientasi evaluatif budaya politik belum maksimal.

KPU Kabupaten Pati dalam melaksanakan sosialisasi politik dan pendidikan politik untuk membentuk perilaku memilih berpusat pada pembentukan perilaku memilih rasional yaitu masyarakat diberi materi pengetahuan politik, didorong serta dimotivasi supaya memilih karena mempertimbangkan visi dan misi para calon yang bertarung dalam Pemilukada, janji kampanye, komitmen, dan prestasi para calon, track record (rekam jejak) serta kepribadian atau akhlak para calon, perilaku para calon dalam kehidupan bermasyarakat, program yang ditawarkan oleh para calon, sedangkan pembentukan perilaku memilih psikologis dan perilaku memilih sosiologis cenderung dikesampingkan karena KPU Kabupaten Pati jarang memberikan materi pengetahuan politik tentang perilaku memilih sosiologis dan perilaku memilih psikologis kepada masyarakat Kabupaten Pati.

KPU Kabupaten Pati dalam melaksanakan sosialisasi politik dan pendidikan politik untuk mengatasi money politics sudah memberikan materi pengetahuan politik tentang money politics supaya masyarakat tidak memilih calon bupati dan wakil bupati karena uang sebab money politics berdampak negatif bagi keberlangsungan sistem politik di suatu negara, selain itu KPU Kabupaten Pati juga mengajak masyarakat untuk bersama-sama menolak money politics dan mengajak masyarakat untuk mengawal Pemilukada Kabupaten Pati tahun 2017 supaya bersih, jujur, bermartabat dan berintegritas. Pemberian materi pengetahuan politik tentang money politics yang dilakukan KPU Kabupaten Pati pada tahap input (masukkan/dukungan) politik belum maksimal karena belum memfokuskan pemberian materi pengetahuan politik tentang bagaimana mekanisme untuk melaporkan apabila terjadi kecurangan dalam proses Pemilukada Kabupaten Pati tahun 2017 seperti 
adanya money politics atau kampanye di tempat yang dilarang untuk berkampanye.

Saran

KPU Kabupaten Pati diharapkan selalu konsisten dalam melaksanakan sosialisasi politik dan pendidikan politik kepada masyarakat Kabupaten Pati untuk masa 5 tahun yang akan datang ketika pemilihan bupati dan wakil bupati tahun 2022 supaya lebih memaksimalkan pemberian materi pengetahuan politik tentang budaya politik terutama aspek pembentukan orientasi evaluatif budaya politik dan aspek pembentukan orientasi afektif budaya politik.

KPU Kabupaten Pati diharapkan selalu konsisten dalam melaksanakan sosialisasi politik dan pendidikan politik kepada masyarakat Kabupaten Pati untuk masa 5 tahun yang akan datang ketika pemilihan bupati dan wakil bupati tahun 2022 supaya konsisten memberikan materi pengetahuan politik tentang perilaku memilih rasional serta memberikan materi pengetahuan politik tentang perilaku memilih sosiologis dan perilaku memilih psikologis sebagai tambahan pengetahuan politik bagi masyarakat Kabupaten Pati.

KPU Kabupaten Pati diharapkan selalu konsisten dalam melaksanakan sosialisasi politik dan pendidikan politik kepada masyarakat Kabupaten Pati untuk masa 5 tahun yang akan datang ketika pemilihan bupati dan wakil bupati tahun 2022 supaya lebih memaksimalkan pemberian materi pengetahuan politik tentang bagaimana mekanisme untuk melaporkan apabila terjadi kecurangan dalam proses pemilihan bupati dan wakil bupati di Kabupaten Pati serta konsisten memberikan materi pengetahuan politik tentang dampak negatif money politics dan dampak positif Pemilukada yang bersih dari money politics.

Profil Singkat

Profil Singkat Penulis Pertama

Galuh Septianingrum dilahirkan di Kota Pati pada tanggal 01 September 1990. Menjalani pendidikan sarjana dari alumnus jurusan PKnH FIS UNY angkatan 2009. Saat profil singkat ini disusun, ia sedang menjalankan semester akhir di Program Pasacasarjana Universitas Negeri Yogyakarta Program Studi PPKn.

\section{Profil Singkat Penulis Kedua}

Dr. Nasiwan, M. Si., dilahirkan pada tanggal 17 April 1965 merupakan dosen pengajar di Fakultas Ilmu Sosial dan Program Pascasarjana Universitas Negeri Yogyakarta. Beliau menjalani pendidikan sarjana S-1 di FISE lulus pada tahun 1994. Kemudian beliau melanjutkan pendidikan ke program pascasarjana S-2 di UGM jurusan Ilmu Politik yang lulus pada tahun 2001. Beliau juga melanjutkan pendidikan di program pascasarjana S-3 jurusan Ilmu Politik UGM yang lulus pada tahun 2015 .

\section{Daftar Pustaka}

Alfian \& Sjamsuddin, N. (1991). Profil budaya politik Indonesia. Jakarta: Pustaka Utama Grafiti.

Almond, G. \& Verba, S. (1984). Budaya politik, tingkah laku politik dan demokrasi di lima negara. (Terjemahan Sahat Simamora). Jakarta: Bina Aksara. (Buku asli diterbitkan tahun 1965).

Asfar, M. (2006). Pemilu dan perilaku memilih 1955-2004. Surabaya: Pustaka Eureka.

Budiardjo, M. (2008). Dasar-dasar ilmu politik. Jakarta: PT. Gramedia Pustaka.

Chilcote, R.H. (2007). Teori perbandingan politik. Jakarta: PT. RajaGrafindo Persada.

Cholisin \& Nasiwan. (2012). Dasar-dasar ilmu politik. Yogyakarta: Penerbit Ombak.

Christopel \& Kuntoro, S.A. (2016). Pemahaman nilai-nilai demokrasi siswa melalui metode inquiri pada pembelajaran pkn di sma negeri 1 gamping sleman. Harmoni Sosial: Jurnal Pendidikan IPS, Vol.3, No. 1, Maret 2016 (14-26), pp. 15.

Gaffar, A. (2006). Politik Indonesia transisi menuju demokrasi. Yogyakarta: Pustaka Pelajar. 
KPU Kabupaten Pati. (2015). Sikap masyarakat Kabupaten Pati dalam politik uang dan implikasinya terhadap keputusan untuk berpartisipasi dan menentukan preferensi politik. Hasil Riset. KPU Kabupaten Pati.

Marijan, K. (2010). Sistem politik Indonesia: konsolidasi demokrasi pasca-orde baru. Jakarta: Penerbit Kencana Prenada Media Group.

Moleong, L.J. (2014). Metodologi penelitian kualitatif edisi revisi. Bandung: Remaja Rosdakarya.

Munadi. (2013). Budaya politik masyarakat Samin (Sedulur Sikep) (studi kasus di Dukuh Mbombong Desa Baturejo Kecamatan Sukolilo Kabupaten Pati Provinsi Jawa Tengah). Jurnal Tesis. Universitas Diponegoro.

Nawawi, H. (2007). Metode penelitian sosial. Yogyakarta: Gajah Mada University Press.

Niemi, R.G., \& Weisberg, H.F. (1984). Controversies of Voting Behavior. Washington D.C.: a Division of Congressional quarterly Inc.

Rahman, A. H.I. (2007). Sistem politik Indonesia. Yogyakarta: Graha Ilmu.

Romli, L. (2008). Kecenderungan pilihan masyarakat dalam pilkada. Jurnal POELITIK. Volume 1.Nomer 1. Jurnal Ilmiah.

Sugiyono. (2016). Metode penelitian kuantitatif, kualitatif, dan $R \& D$. Bandung: Alfabeta.

Wijayanti, A. (2009). Pilihan pemilih terhadap calon anggota DPRD Kabupaten Pati dalam pemilu legislatif 2009. Skripsi. Universitas Negeri Semarang.

Zamroni. (2001). Pendidikan untuk demokrasi. Yogyakarta: BIGRAF Publishing. 